\title{
News and Notices
}

\section{Men in Black: Jesuits in Mystery Fiction}

\author{
Judith Rock \\ Independent scholar, Sarasota, FL, USA \\ wingrock@att.net
}

Mystery novels and thrillers-like films of the exploding car variety-often feature mysterious men in black as forces to be reckoned with. In her blog for June 3, 2019, mystery writer Annamaria Alfieri discusses mysteries featuring or including Jesuit characters and calls Jesuits the original men in black.

Writers have created Jesuit characters since at least the seventeenth century. Until the twentieth century, these usually sinister men in black mostly inhabited anti-Jesuit polemic thinly disguised as fiction. In August 1900, the Boston College Review published an article called "The Jesuit in Fiction," by Walter E. M'Cann. In nineteenth-century England, he says that

almost everything that happened was ascribed to the Jesuits-from the overturnings of empires to volcanic eruptions and earthquakes - and even to this day there are still a few shrewd folk who are sure that the followers of St. Ignatius are at the bottom of most important events, especially those of sinister character, that occur in the world. I know it was confidently stated in a weekly publication after the election of President McKinley that it was the Jesuits who placed him in the White House, and a few years ago..., a clergyman one Sunday night announced to the congregation before him his positive information from a reliable source that Pope Leo XIII had been dead for some time, and that the person really occupying the Papal chair, in appropriate and necessary stage make-up, was Father Martin, the General of the Jesuits (1). 
Heinrich Bornstein's polemical novel, The Mysteries of St. Louis, was first published in German in St. Louis, in 1851. Bornstein was a radical leftist and friend of Marx and Engels. His sinister Jesuits-and others-are searching for a hoard of gold and jewels buried near the city, perhaps under what is now St. Louis University. If the Jesuits find it first, they will use it to buy huge tracts of western land and re-establish the Holy Roman Empire.

Contemporary mysteries feature many religious and clergy, but even the Jesuits among them are rarely sinister. Nuns like Margaret Frazer's Benedictine Dame Frevisse, monks like Ellis Peters's beloved Benedictine Brother Cadfael, members of other Catholic religious orders, diocesan priests, rabbis, and Protestant clergy solve crimes, often as main characters in long running series. Though I'm not aware of imams or Buddhist monks as fictional sleuths, they may well be tracking down criminals in someone's novels.

In 2006, the late Gerald McKevitt, S.J., established the "Jesuits in Fiction" archive at Santa Clara University, Santa Clara, California. The collection, housed in the university library, includes works from the seventeenth century to the present. Novels constitute most of the collection, but drama, poetry, anti-Jesuit diatribes, audio visuals, and manuscripts are also included. Because novels in the archive are not identified by genre, I went through the nineteenth-, twentieth-, and twenty-first-century lists looking for mystery novels. Considering title, author, and publisher, and cross-checking by classification in online booklists, I found twenty mysteries with Jesuit characters. I also found other genre novels with Jesuit characters, including nine science fiction and several thrillers.

In the mystery novels with Jesuit characters that I read for this essay, I looked for why the authors had made the characters in question Jesuits. Jesuits, trained to think logically, but also compassionately, seem an obvious choice for sharp-eyed, fictional sleuths. I had not imagined Jesuits on other planets, but intellectual curiosity, ingenuity, and courage could well account for Jesuit interplanetary travel. As for the very surprising vampire novels, I could only wonder-admittedly tongue in cheek — if the famous Jesuit openness to other cultures might account for the relationships with vampires.

The Santa Clara archive includes F. H. Batacan's brilliant Smaller and Smaller Circles (2015), winner of the Philippine National Book Award. It is set in contemporary Manila. Jesuits are often called the intellectuals of the church, working and creating from complexity. Batacan's pair of Jesuit main characters embody that statement. The older of them is Father Gus Saenz, a forensic anthropologist. The younger is Father Jerome Lucero, his protégé and a psychologist and psychology professor. Both men are profoundly committed to the poor and to social justice. They live out, at high cost to themselves, 
the distinctive Jesuit ministry as described by Jerónimo Nadal, one of Ignatius of Loyola's companions and collaborators: "The Society has the care of those souls for whom either there is nobody to care or, if somebody ought to care, for whom the care is negligent" (see Robert A. Maryks, "Assigned Viewing," Boston College Magazine [Summer 2015], https://bcm.bc.edu/index.html\%3Fp=4449. html).

The novel's very grizzly murders happen in Manila's worst slums, and in the shadow of appalling and banally common secular and ecclesiastic choices, and the deadly grip on power they serve. Batacan's story is as realistic and unromantic as a mortuary slab. It seems to me that Saenz and Lucero are sustained by the Jesuit ideal of finding God in everything: God, perhaps, as the flare of light, however small, marking the place in the heart and in the world where the beating back of unbearable darkness and cruelty begins, and where compassion also begins.

Among the mysteries with Jesuit characters not yet in the Santa Clara archive are novels by two American authors who take readers to places which, like Manila, are unusual as mystery settings. Annamaria Alfieri, a well-known and prolific mystery writer, takes her readers to $165^{\circ}$ Peru, in City of Silver (2009), and to mid-nineteenth-century Paraguay in Invisible Country (2012). Susan Spann, an American attorney living in Tokyo, sets her long running mystery series in sixteenth-century Japan.

I read the seventh book in Spann's series, Ghost of the Bamboo Road (2019), and then the first book, Claws of the Cat (2013). Spann evokes 156os Japan in fascinating detail. Her descriptions of landscapes, buildings, clothing, food, beliefs, and customs; of the uneasy shogunate politics of the time; and of many kinds of people, show loving and tireless research.

In Annamaria Alfieri's June 3, 2019 mystery blog, Spann says that she wanted a Catholic priest in the stories, and that her priest is a Jesuit because Jesuits were the only Catholic priests in Japan at the time. Father Mateo Ávila de Santos is also a narrative device. The author says that one of his functions is to connect Western readers to Japanese culture through a Western gaze. Which, of course, with his distinctively Jesuit openness to and interest in Japanese culture, he is well suited to do, and does well.

In some ways, though, as a Jesuit, Father Mateo seems to me less clearly drawn than the other main character Hiro, a Samurai and Shinobi /Ninja. Hiro and Father Mateo say that Hiro is Father Mateo's scribe. But the real reason for Hiro's constant presence is his mysterious oath to protect the Jesuit. We soon see that the Shinobi /Ninja is the dominant character and that Father Mateo often functions as his sidekick. 
The house where the two of them live in Kyoto is also the Jesuit church. But we rarely see or hear anything of Father Mateo's work as a missionary. He is concerned about people and injustice, and we see him praying alone with his Bible, and with converts one at a time. He is never shown saying Mass or preaching, which Jesuits in Japan did, in spite of anti-Christian danger. They also attracted converts by creating theatrical performances based on Scripture stories, which were attended by large Japanese audiences.

Father Mateo is a lone Jesuit. Jesuits often were alone in parts of Japan, but Father Mateo never mentions the Jesuit superior he would surely have had, whether in Japan or elsewhere. In the two books I read, he does not mention any other Jesuit, though the series' first book is set in Kyoto in 1564, where Father Gaspar Vilela, a real Portuguese Jesuit, arrived in the spring or summer of 1563 , and where new missionaries joined him in 1564 and 1565 , as Hubert Cieslik, S.J., relates in his 1954 account, Early Missionaries in Japan (Sophia University Private Collection, 6, 7, 9).

And finally, and puzzlingly, Father Mateo sometimes wears the two characteristic Samurai swords when he goes out in Kyoto, though he wears them badly and the result is nicely comic. He wears them because Hiro tells him that this enhances his social position in the eyes of the Japanese. But Ignatius of Loyola forbade even the presence of weapons in any Jesuit house, so it is startling that a Jesuit anywhere would wear weapons in the street.

Even if most readers do not notice — or care about — these questions, careful accuracy about the Jesuits in sixteenth-century Japan seems to me as important as accuracy about the period's Japanese culture and characters. Without it, both the Jesuit and the historical group to which he belongs are falsified, and the story loses some of its potential color.

I say this out of my own discoveries while writing four historical mystery novels, The Rhetoric of Death (New York: Berkley Books, 2010), The Eloquence of Blood (New York: Berkley Books, 2011), A Plague of Lies (New York: Berkley Books, 2012), and The Whispering of Bones (New York: Berkley Books, 2013), three of which are in the Santa Clara archive. They are set in 168os Paris, and a young Jesuit, Charles du Luc, is the main character and sleuth. He teaches rhetoric and helps produce ballets at the Jesuit school called Louis le Grand, on the rue St. Jacques. I wanted to bring readers as far, and as accurately, into late-seventeenth-century Paris and Jesuit life there as I possibly could. Otherwise the characters and crimes, part of a world not ours, a world inhabited by people not us, could not be understood as they needed to be. This meant that I had to paint the novels' pair of detectives, my fictional Jesuit Charles and Nicolas de la Reynie, Paris's real first police chief, as clearly and accurately as possible, though the facts about them and their situation were 
often inconvenient to me and to the plot! But every time I let the truth of the characters and their century change the story, the story grew richer and more interesting. It did not matter that most readers would not recognize inaccuracies, whether inadvertent or convenient.

Though my assignment for this essay was Jesuits in mystery fiction, I could not resist a look at the Jesuit in a science fiction novel in the Santa Clara archive, and the Jesuit in two vampire novels.

Mary Doria Russell's beautifully written Father Emilio Sandoz in her novel The Sparrow (New York: Ballantine Books, 1996) is the pre-eminent example of a Jesuit character in science fiction. The Sparrow won numerous science fiction awards, including the Arthur C. Clarke prize. It was followed by a sequel, Children of God (New York: Ballantine Books, 1998).

The story opens in December 2059. Father Sandoz, a linguist, has returned to Earth as the seriously wounded sole survivor of a Jesuit scientific mission to make contact with intelligent extraterrestrials. The story is driven by a pressing mystery. What happened on the planet Rakhat, where Father Sandoz and his team were? Was whatever happened his fault? Why is he the sole survivor? Father Sandoz refuses to answer these questions. We first meet him in a Jesuit house on St. Peter's Square, where he has been sent, still very ill, from a Roman hospital. He is under serious suspicion and must clear himself, if he can-or will—in the eyes of the Society of Jesus, whose mission he and his fellow space travelers undertook. Besides Russell's impeccable and beautiful writing, what interested me immediately in this story, though I rarely read science fiction, is the detailed Jesuit reality of Father Sandoz's life and situation, and how that shapes the story. Though the story is fantasy set a few years in the future, its main character is a three-dimensional, late-twentieth-century Jesuit. It is his detailed reality and struggle as a human being and a Jesuit, and the real-world consequences facing him and the Society of Jesus, that grip us, draw us into the story, and ground the science fiction.

The two vampire novels I discovered were a surprise, to say the least. They are by Carlos Dews and S. J. Rozan writing as Sam Cabot. In Annamaria Alfieri's June 3, 2019, mystery blog, mentioned above, Dews acknowledges that the books owe something to the Dan Brown oeuvre. (About which so much has been said, that perhaps no more need be added.) The first Sam Cabot book is called Blood of the Lamb (New York: Blue Rider, 2014). Dews made the novels' priest character a Jesuit because he considers the Society of Jesus the church's intellectuals (6). Father Thomas Kelly, a graduate of Boston College and a church historian, is asked to find a document concerning an ancient Catholic Church secret, for which other and dangerous searchers are also looking. If found and revealed, this document could destroy the church. As Father Kelly 
searches Roman archives, an art historian, Livia Pietro, joins and helps him. The secret involves vampires, and the young woman reveals herself as one of them. It also involves, among many other things, blood from Catholic hospitals. The second in the pair of novels is Skin of the Wolf (New York: Blue Rider, 2015), in which there are werewolves in New York City's Central Park. Like the first book, it features vampire Livia Pietro and Father Kelly, who is now on a list to become a vampire.

Leaving aside these other genres, I have often thought about why so many amateur detectives in mystery fiction are members of religious orders and clergy of various sorts. They are certainly not the majority of fictional amateur sleuths, but their presence is, so far, continuous in the genre. It has been said that classic mystery fiction is the most morally driven fiction. Mystery writers give us a particular world, whether a family, a village, a government, a school, a monastery, or some other fairly small group of people, whose privacy is ripped open, whose business as usual is brought to a sudden stop, by a crime, usually murder. The discovered crime, the result of some secret fear or greed or hatred, exposes other destructive secrets that have been hidden in the particular world's fabric. The solving of the crime involves the laying bare and purging of some of these secrets, the discovery of the criminal, and his or her removal from the community in question, so that he or she cannot do more harm. But we are always reminded that that is not the end. The fabric of the small world in which the crime was done has now to be repaired, so that the innocent no longer suspect each other and trustworthy connections are rebuilt. The solving of the murder is a kind of redemption. The world concerned can then become not only itself again, but itself more fully. Seen in this way, mystery fiction reveals human brokenness, and its detectives insist on unwanted truth that brings first suffering, and then healing. It is easy to see why many mystery writers choose clerics and religious, including Jesuits, for this task. 